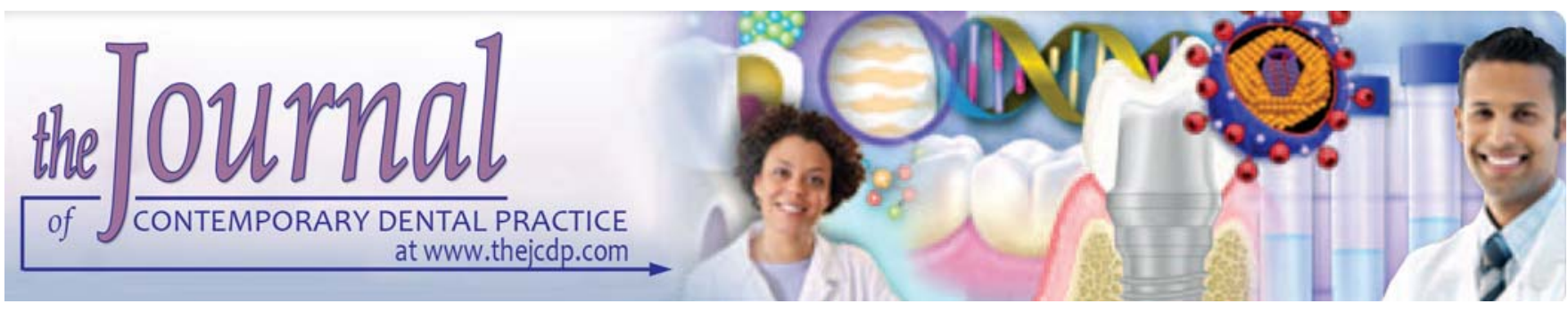

\title{
Clinical and Histological Comparison of Polyglycolic Acid Suture with Black Silk Suture after Minor Oral Surgical Procedure
}

R Balamurugan, Masroor Mohamed, Vijayendra Pandey, Hari Krishna Rao Katikaneni, KR Ashok Kumar

\begin{abstract}
Any suture material, absorbable or nonabsorbable, elicits a kind of inflammatory reaction within the tissue. Nonabsorbable black silk suture and absorbable polyglycolic acid suture were compared clinically and histologically on various parameters.
\end{abstract}

Materials and methods: This study consisted of 50 patients requiring minor surgical procedure, who were referred to the Department of Oral and Maxillofacial Surgery. Patients were selected randomly and sutures were placed in the oral cavity 7 days preoperatively. Polyglycolic acid was placed on one side and black silk suture material on the other. Seven days later, prior to surgical procedure the sutures will be assessed. After the surgical procedure the sutures will be placed postoperatively in the same way for 7 days, after which the sutures will be assessed clinically and histologically.

Results: The results of this study showed that all the sutures were retained in case of polyglycolic acid suture whereas four cases were not retained in case of black silk suture. As far as polyglycolic acid suture is concerned 25 cases were mild, 18 cases moderate and seven cases were severe. Black silk showed 20 mild cases, 21 moderate cases and six severe cases. The histological results showed that 33 cases showed mild, 14 cases moderate and three cases severe in case of polyglycolic acid suture. Whereas in case of black silk suture 41 cases were mild. Seven cases were moderate and two cases were severe. Black silk showed milder response than polyglycolic acid suture histologically.

Conclusion: The polyglycolic acid suture was more superior because in all 50 patients the suture was retained. It had less tissue reaction, better handling characteristics and knotting capacity.

Keywords: Polyglycolic acid, Black silk, Absorbable, Nonabsorbable black silk.

How to cite this article: Balamurugan R, Mohamed M, Pandey V, Katikaneni HKR, Kumar KRA. Clinical and Histological Comparison of Polyglycolic Acid Suture with Black Silk Suture after Minor Oral Surgical Procedure. J Contemp Dent Pract 2012;13(4):521-527.

\section{Source of support: $\mathrm{Nil}$}

Conflict of interest: None declared

\section{INTRODUCTION}

Sutures have been used to close wounds as early as 50,000 BC. Selection of a suture material is as important as its placement. Perfect suture material do not exist; characteristics of this elusive material are nonreactivity, retention of tensile strength until healing has occurred and easy handling. ${ }^{1}$ It should also then disappear by chemical reaction rather than by foreign body degradation. Suture materials are generally classified into two categories; nonabsorbable and absorbable. ${ }^{1}$ The nonabsorbable types are silk, cotton, nylon, polyester (D acron) polyprophylene (prolene) and stainless steel. Nylon and steel are available in both monofilament and multifilament forms. Polypropylene is available as monofilament only. Braiding of synthetic material was designed to improve handling qualities and knot holding capacity.

The absorbable materials include catgut, collagen, polyglycolic acid (dexon) and polymeard glycolic and lactic acid (vicryl). ${ }^{2}$

The polymers-polyglycolic and copolymer of glycolic and lactic acid are relatively recent additions to the surgeons armamentarium and are quite similar in physical properties. Despite claims for delayed resorption, there is a demonstrable tensile strength after 14 to 21 days. ${ }^{2}$ Other polymeric material is dependent on enzymatic degradation. They are slowly hydrolyzed by water, which occurs more rapidly at an alkaline $\mathrm{pH}$. The presence of infection yields on an acidic $\mathrm{pH}$ which will delay dissolution. ${ }^{2,3}$

A new absorbable suture material, polyglycolic acid (PGA ; D exon), was synthesized in 1968, polyglycolic acid is the homopolymer of hydroxyacetic acid (glycolic acid). This high molecular weight linear-chain polymer (polyester) is liquefied and extruded through spinnerets to form continuous filaments. These filaments are oriented by 
stretching and then are combined by braiding to form sutures of different diameters. The polyglycolic acid suture material was reported to meet more closely the requirements of the ideal suture material. ${ }^{3}$

The purpose of this study was to examine tissue reaction to two different types of suture materials placed in densely fibrous gingiva and in oral mucosa after minor surgical procedures. No histological comparisons betw een intraoral suture materials have been done in humans.

\section{MATERIALS AND METHODS}

This study consisted of 50 patients, referred to the Department of Oral and M axillofacial Surgery requiring minor surgical procedure. Patients was selected randomly and sutures were placed in the oral cavity 7 days preoperatively. Polyglycolic acid sutures were placed on one side and black silk sutures was placed on the other side.

The polyglycolic acid sutures are packaged as a dry product. So we used this absorbable synthetic material, polyglactin 910 [coated vicryl undyed braided 4-0 (ethicon)] suture material on one side and on the other side we used nonabsorbable organic material silk [black braided silk. 4-0 (ethicon)], black silk suture material.

The suture material was intraorally placed presurgically in visible areas for 7 days (Figs 1 and 2). Following placement of the suture, the examination of the tissue was assessed for clinical changes and then removed along with the little of the specimen which will be histologically examined.

A fter the minor surgical procedure like exodontia, surgical removal of impacted teeth, alveoplasty, etc. again sutures will be placed in the same way bilaterally and 7 days later postoperatively clinical assessment in terms of various parameters, ${ }^{4}$ such as appearance where in we check for any reaction which were classified as:

1. M ild erythema

2. M oderate erythema

3. Evidence of severe generalized erythema.

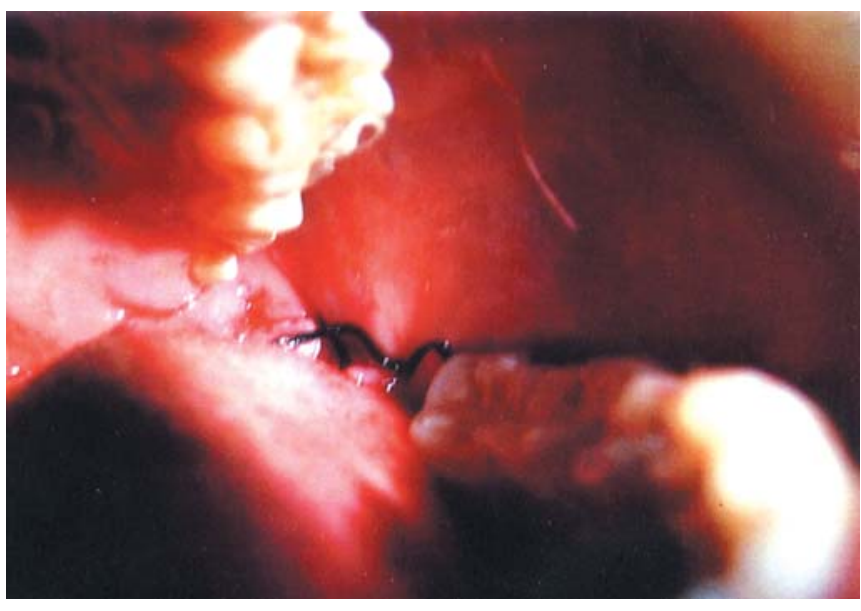

Fig. 2: Closure with black silk suture

Then we check for retention of suture, whether sutures were retained or not; evidence of complication wherein we check for presence/absence of pus and finally for any patient complaints.

The histologic examination of the specimen was done on the basis of presence/absence of inflammatory cells and the type-acute, subacute and chronic and also we check for intensity- mild, moderate and severe (Figs 3 to 6).

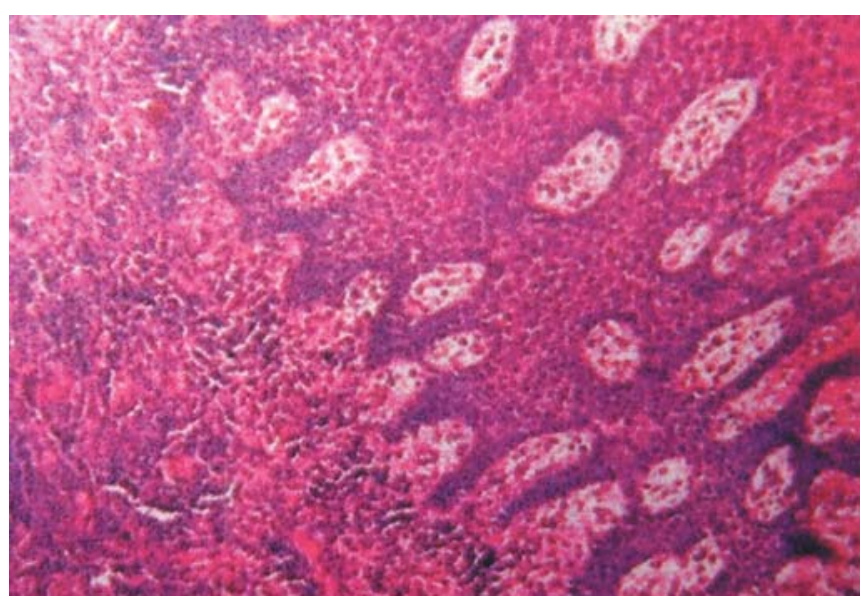

Fig. 3: Preoperative black silk suture

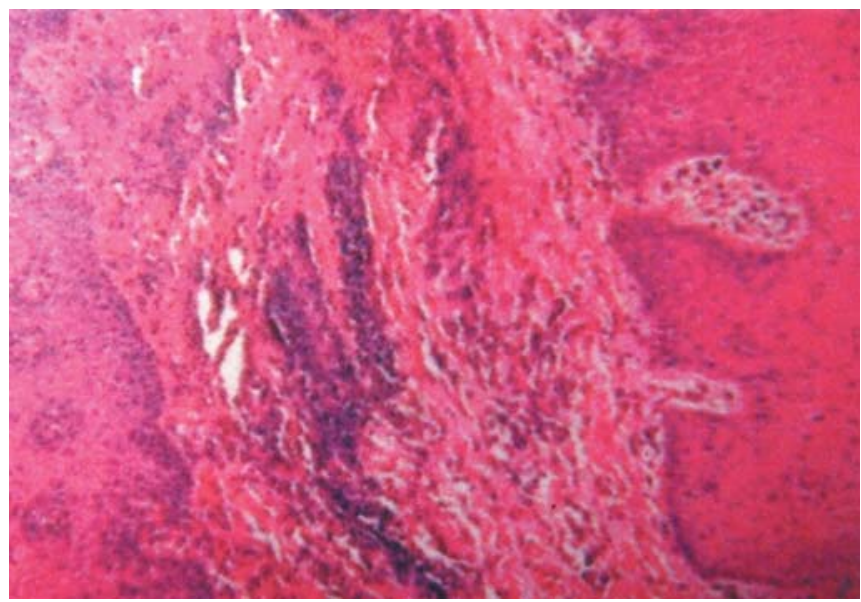

Fig. 4: Postoperative black silk suture

Fig. 1: Closure with polyglycolic acid suture

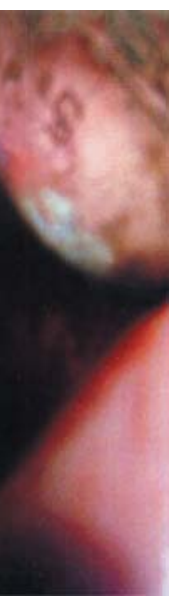




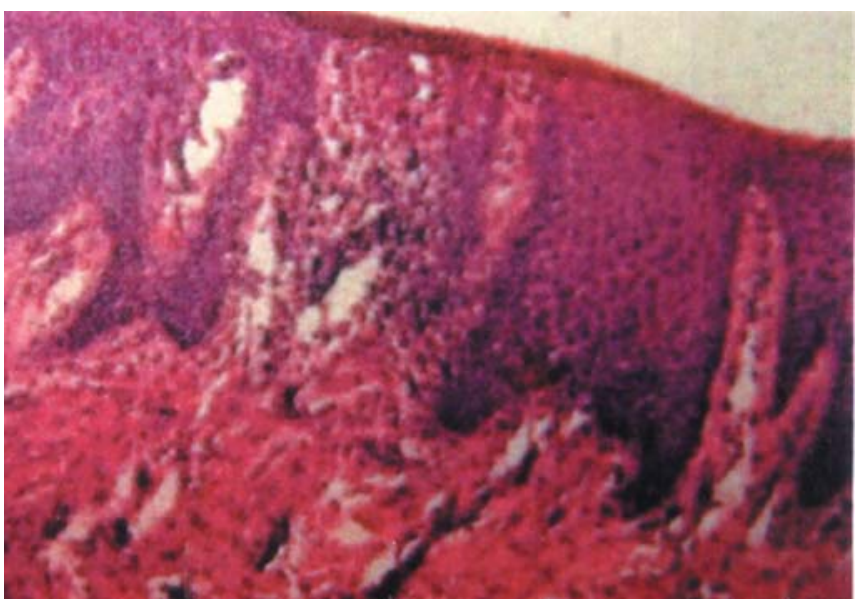

Fig. 5: Preoperative polyglycolic acid suture

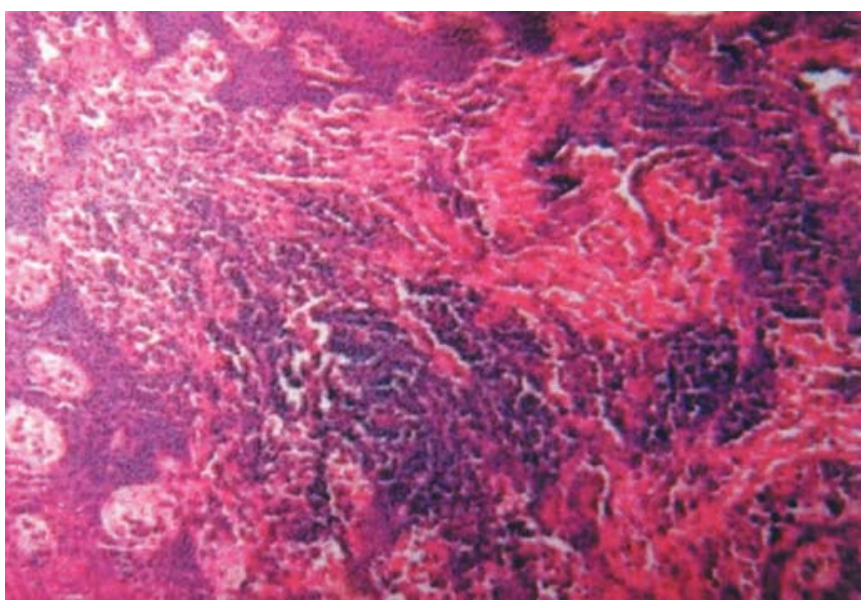

Fig. 6: Postoperative polyglycolic acid suture

Only patients who are voluntarily willing for this study were selected.

\section{RESULTS}

Clinical examination under various parameters and histological comparison of polyglycolic acid suture and black silk suture was done. The results and observations of this study was such that:

A bout 22 cases ( $45 \%$ of the total cases) were in the age group of 16 to 25 years, about 21 cases were in the age group of 26 to 35 , two cases in the age group of 36 to 45 , two from the age group of 46 to 55 , one from the age group of 56 to 65 and two from the 66 to 75 age group (Table 1 and Graph 1).

The sexwise distribution showed 36 male patients and 14 female patients: 72 and $28 \%$ respectively (Table 2 and Graph 2).

The sutures were clinically examined postoperatively after 7 days of placement (Figs 7 and 8); the findings were tabulated as in for appearance was about 31 cases showing mild changes, 17 cases moderate changes and two cases severe changes in polyglycolic acid suture material. ${ }^{5}$ Whereas in case of black silk sutures 27 cases were mild, 20 cases were moderate and 3 cases were severe (Table 3 ).

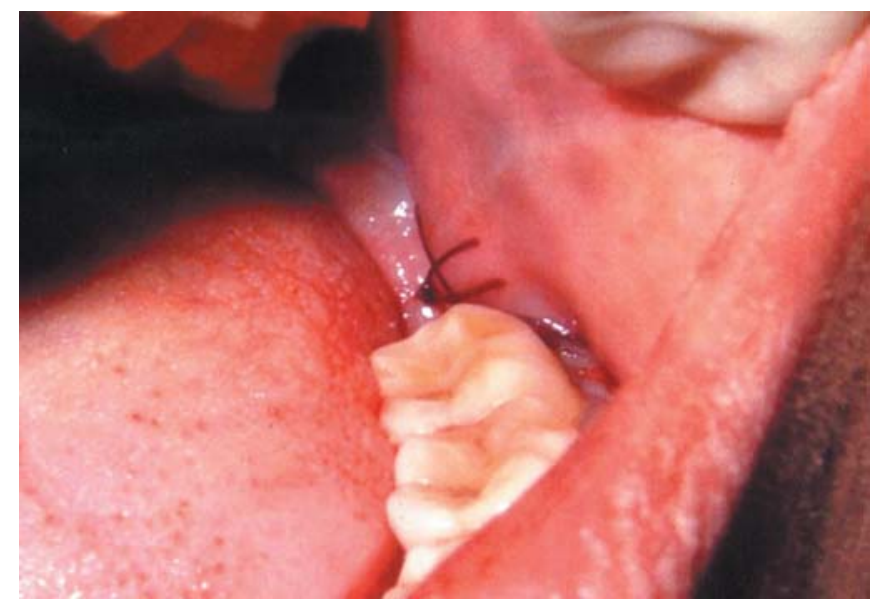

Fig. 7: Appearance of polyglycolic acid suture

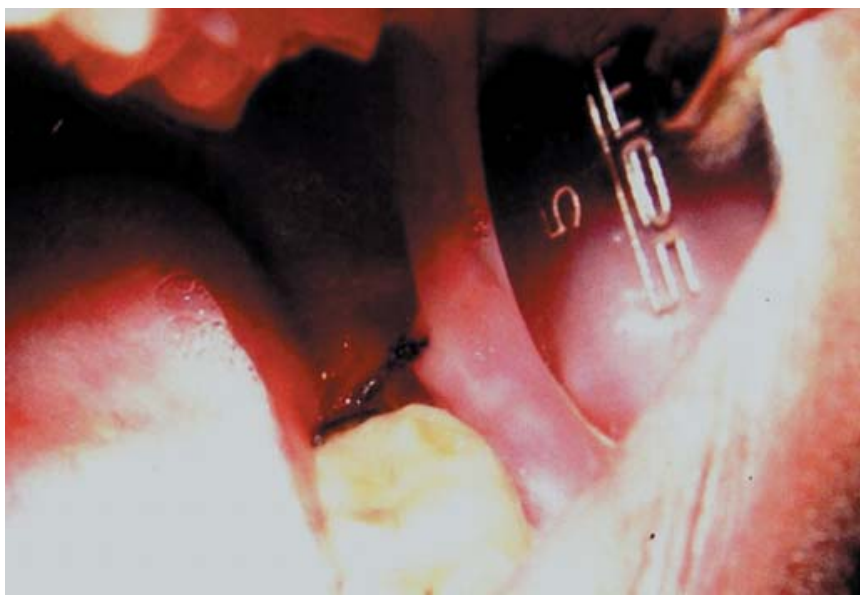

Fig. 8: Appearance of black silk suture after 7 days

\begin{tabular}{lcc}
\multicolumn{3}{c}{ Table 1: Agewise distribution } \\
\hline Age (year) & No. of cases & Percentage \\
\hline $16-25$ & 22 & 44 \\
$26-35$ & 21 & 42 \\
$38-45$ & 2 & 4 \\
$46-55$ & 2 & 4 \\
$56-65$ & 1 & 2 \\
$66-75$ & 2 & 4 \\
\hline Total & 50 & 100 \\
\hline
\end{tabular}

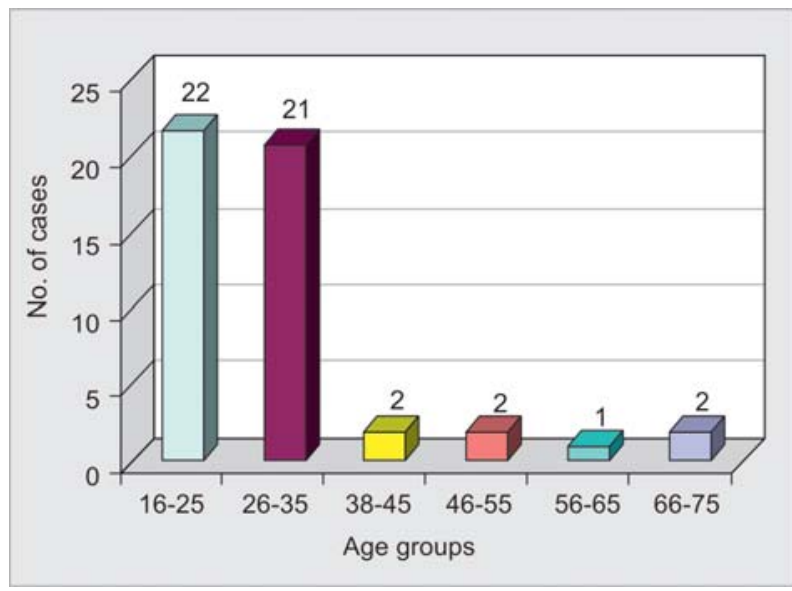

Graph 1: Agewise distribution 


\begin{tabular}{lcc} 
& Table 2: Sexwise distribution \\
\hline Sex & Number & Percentage \\
\hline Male & 36 & 72 \\
Female & 14 & 28 \\
\hline Total & 50 & 100 \\
\hline
\end{tabular}

A s far as the retention of suture materials is concerned in all 50 patients, polyglycolic acid suture was retained where as in four cases the black silk suture material was not retained. No cases showed any complications (pus was not positive in any of the cases). Since, the patients were al ready motivated for the study no complaints from the patients was recorded.

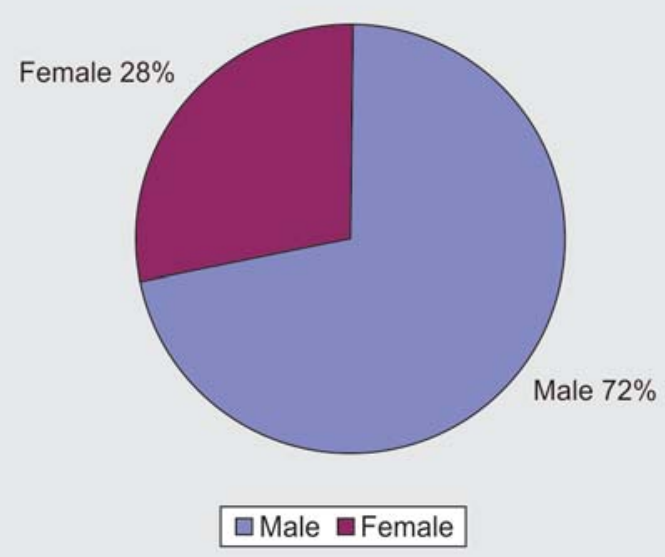

Graph 2: Sexwise distribution

\section{Postoperative}

In the histological study inflammatory cells was present in all the cases; 26 cases were acute, 18 cases were subacute and six cases were chronic (Graph 3). The intensity varied as 34 cases were mild, eight cases were moderate and eight cases were severe in case of polyglycolic acid suture (Graph 4). In case of black silk suture about 32 cases was acute, 10 cases were subacute and eight cases were chronic and the intensity varied as the 34 cases were mild, 10 cases were moderate and eight cases were severe Table 4.

The postoperative clinical examination showed 25 cases as mild, 18 cases as moderate and seven cases severe. In all the 50 cases the suture materials was retained. There was

\begin{tabular}{|c|c|c|c|c|c|}
\hline \multirow[t]{2}{*}{ Findings } & & \multirow{2}{*}{$\begin{array}{l}\text { PAS } \\
n(\%)\end{array}$} & \multirow{2}{*}{$\begin{array}{l}\text { BSS } \\
n(\%)\end{array}$} & \multicolumn{2}{|c|}{ Difference } \\
\hline & & & & $\chi^{2}$ & $\mathrm{p}$ \\
\hline \multirow[t]{3}{*}{ Appearance } & Mild & $31(62)$ & $27(54)$ & 0.72 & $0.70, \mathrm{NS}$ \\
\hline & Moderate & $17(34)$ & $20(40)$ & & \\
\hline & Severed & $2(4)$ & $3(6)$ & & \\
\hline \multirow[t]{2}{*}{ R etention of suture } & Retained & $50(100)$ & $46(92)$ & 2.34 & NS \\
\hline & Not retained & - & $4(8)$ & & \\
\hline Evidence of complication & Pus negative & $50(100)$ & $50(100)$ & - & - \\
\hline Patient complaint & No & $50(100)$ & $50(100)$ & - & - \\
\hline
\end{tabular}

NS: Not significant

\begin{tabular}{|c|c|c|c|c|c|}
\hline \multirow[t]{2}{*}{ Findings } & & \multirow{2}{*}{$\begin{array}{l}\text { PAS } \\
n(\%)\end{array}$} & \multirow{2}{*}{$\frac{\text { BSS }}{n(\%)}$} & \multicolumn{2}{|c|}{ Difference } \\
\hline & & & & $\chi^{2}$ & $p$ \\
\hline Inflammatory cells & Present & $50(100)$ & $50(100)$ & & \\
\hline \multirow[t]{3}{*}{ Type } & Acute & $26(52)$ & $32(64)$ & 3.19 & $0.20, \mathrm{NS}$ \\
\hline & Subacute & $18(36)$ & $10(20)$ & & \\
\hline & Chronic & $6(12)$ & $8(16)$ & & \\
\hline \multirow[t]{3}{*}{ Intensity } & Mild & $34(68)$ & $32(64)$ & 0.28 & 0.87 , NS \\
\hline & Moderate & $8(16)$ & $10(20)$ & & \\
\hline & Severe & $8(16)$ & $8(16)$ & & \\
\hline
\end{tabular}

NS: Not significant

\begin{tabular}{|c|c|c|c|c|c|}
\hline \multirow[t]{2}{*}{ Findings } & & \multirow{2}{*}{$\begin{array}{l}\text { PAS } \\
\mathrm{n}(\%)\end{array}$} & \multirow{2}{*}{$\begin{array}{l}\text { BSS } \\
\mathrm{n}(\%)\end{array}$} & \multicolumn{2}{|c|}{ Difference } \\
\hline & & & & $\chi^{2}$ & $p$ \\
\hline Appearance & $\begin{array}{l}\text { Mild } \\
\text { Moderate } \\
\text { Severed } \\
\text { No reaction }\end{array}$ & $\begin{array}{l}25(50) \\
18(36) \\
7(14) \\
-\end{array}$ & $\begin{array}{l}27(54) \\
20(40) \\
6(12) \\
3(6)\end{array}$ & 3.86 & 0.28, NS \\
\hline R etention of suture & Retained & $50(100)$ & $50(100)$ & - & - \\
\hline Evidence of complication & Pus negative & $50(100)$ & $50(100)$ & - & - \\
\hline Patient complaint & No & $50(100)$ & $50(100)$ & - & - \\
\hline
\end{tabular}

NS: Not significant 
Clinical and Histological Comparison of Polyglycolic Acid Suture with Black Silk Suture after Minor Oral Surgical Procedure

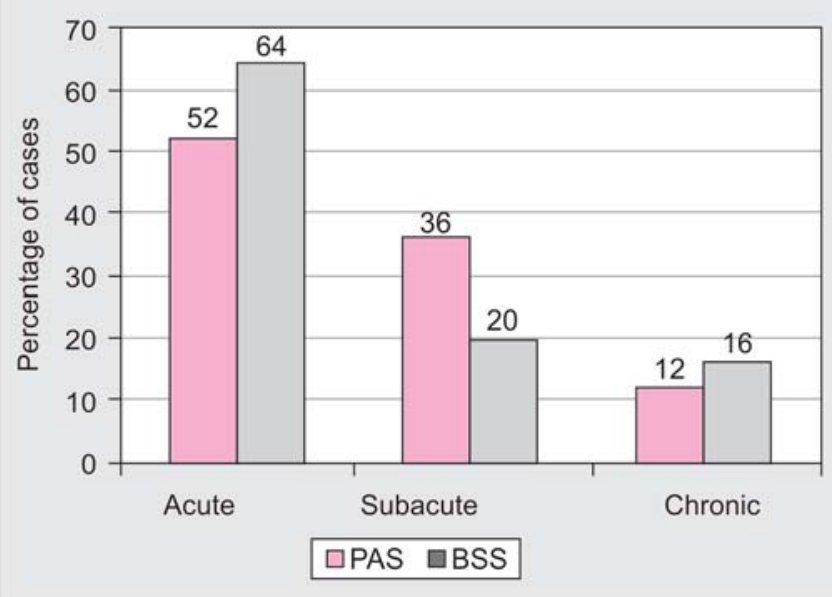

Graph 3: Postoperative histological comparisons: Type

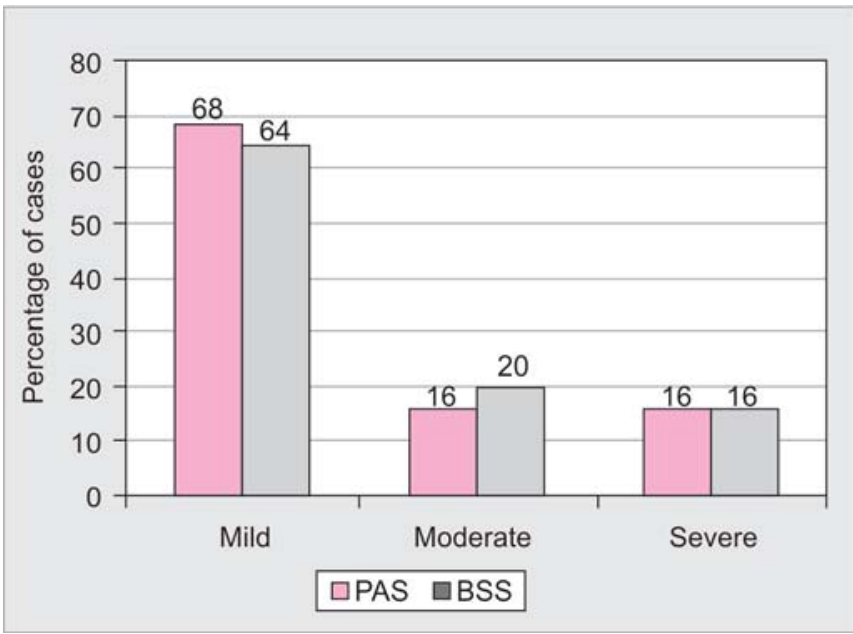

Graph 4: Postoperative histological comparisons: Intensity

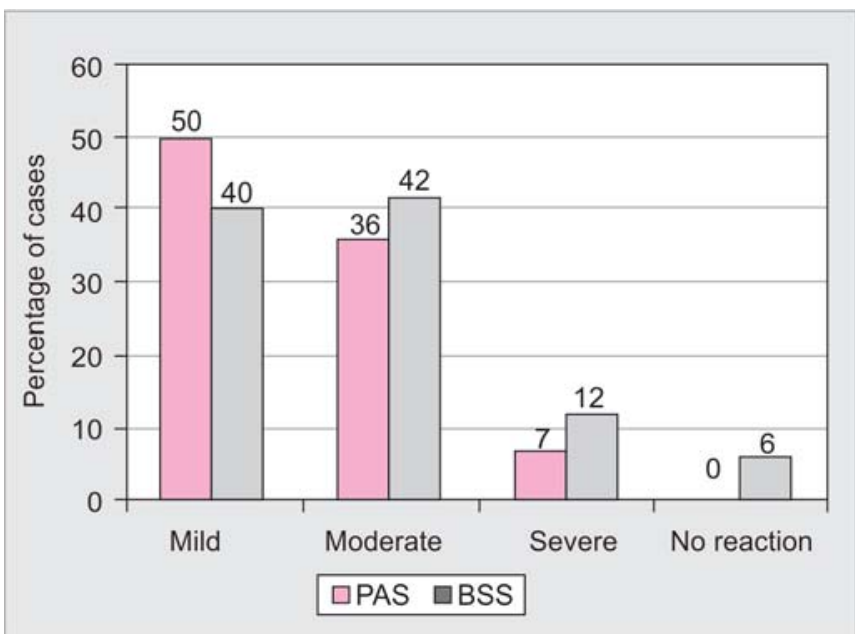

Graph 5: Clinical examination: Postoperative appearance

no evidence of complications and no patient's complained in case of polyglycolic acid suture material.

For the black silk suture material, 20 cases showed mild reaction, 21 cases showed moderate changes, six cases showed severe changes and three cases had no reaction. In all the cases sutures were retained and there was no evidence of complication (pus was not positive in any of the cases) and also no patients complained (Table 5 and Graph 5).

Histological examination (Table 6), inflammatory cells were present in all the cases (Figs 3 to 6). In case of polygylcolic acid suture, 33 cases were acute, 14 cases were subacute and three cases were chronic and the intensity varied as 33 cases were mild, 14 cases moderate and three cases were severe.

In case of black silk suture, 41 cases were acute, seven cases were subacute and two cases were chronic and the intensity varied as 41 cases mild, seven cases moderate and two cases were severe.

\section{DISCUSSION}

The history of surgery is one that of constant progress in wound closure techniques. An Egyptian scroll (3500 BC) describes that the world's oldest suture was placed by an embalmer on the belly of a twenty-first dynasty mummy dating back to $1100 \mathrm{BC}$. In the Indian context, the Sustruta's Samhita in 600 BC, there is a mention of suture materials made from animal sinews, braised horse hair, leather slips and vegetable fibers. The word suture was a Latin word meaning 'Sutura or a seam/stitch', Suture can be defined as a material used in closing surgical or traumatic wound with stitches made to secure opposition of edges of a surgical or accidental wound. ${ }^{5,6}$

\section{Suture Selection}

Closure of a wound is performed so that primary closure will be followed by: (a) 0 bliteration of dead space, (b) even distribution of renaming tension along deep suture lines, (c) maintenance of tensile strength across the wound by suture until the tissue tensile strength is adequate and (d) approximate eversion of epithelial portion of closure, are dependent upon satisfactory performance of above tasks.

Indications for suture: ${ }^{7}$

1. Tissue approximation

2. For ligation of vessels

3. For good and faster healing

4. Hemostasis

5. For tongue tie

6. For marking the border in wide excision

7. To minimize wound closure tension

8. Reduce wound dead space

9. To provide wound eversion

10. To minimize the risk of hematoma formation. 


\begin{tabular}{|c|c|c|c|c|c|}
\hline \multicolumn{6}{|c|}{ Table 6: Histological comparisons } \\
\hline \multirow[t]{2}{*}{ Findings } & & \multirow{2}{*}{$\begin{array}{l}\text { PAS } \\
n(\%)\end{array}$} & \multirow{2}{*}{$\begin{array}{l}\text { BSS } \\
n(\%)\end{array}$} & \multicolumn{2}{|c|}{ Difference } \\
\hline & & & & $\chi^{2}$ & $\mathrm{p}$ \\
\hline Inflammatory cells & Present & $50(100)$ & $50(100)$ & - & - \\
\hline \multirow{3}{*}{ Type } & Acute & $33(66)$ & $41(82)$ & 3.40 & $0.18 \mathrm{NS}$ \\
\hline & Subacute & $14(28)$ & $7(14)$ & & \\
\hline & Chronic & $3(6)$ & $2(4)$ & & \\
\hline \multirow[t]{3}{*}{ Intensity } & Mild & $33(66)$ & $41(82)$ & 3.40 & $0.18 \mathrm{NS}$ \\
\hline & Moderate & $14(28)$ & $7(14)$ & & \\
\hline & Severe & $3(6)$ & $2(4)$ & & \\
\hline
\end{tabular}

NS: Not significant

\section{Tissue Reaction}

Standards for suture were first introduced in the United States Pharmacopeia (USP) in $1937 .{ }^{8}$ To meet the standard for each size, the average strand diameter must remain within definite limits and must meet minimum tensile strength. Requirements of the USP specifications are listed in three categories; (a) collagen suture synthetic, (b) absorbable suture, (c) nonabsorbable suture.

The coefficient of friction of a given suture is determined by filament type, material and coating used. In general, monofilaments have lowest coefficient of friction and cause the least amount of tissue injury. Elasticity of a suture can also affect the amount of tissue injury. ${ }^{8}$

Tissue reaction to sutures could be due to material composition or antigenicity of sutures, coating agents or to physical properties of the same. Tissue reactions secondary to physical properties of sutures can be attributed to the capillary and fluid absorption profile of the suture.

\section{Absorbable Suture}

The term absorbable suture implies absorption and eventually disappearance of the suture from the tissue implantation site. The rate of absorption depends on the type of materials used and the condition of the tissue. Selecting a specific absorbable suture requires assessment of the length of time the material is maintained and the strength it has over that time. A bsorbable sutures are eventually absorbed by the body, as a result of either of the two processes as follows:

a. Enzymatic action: Digestion by proteolytic enzymes derived from lysozymes contain within polymorphs and macrophages. ${ }^{8,9}$

b. Hydrolysis: The effect of water on the suture material does not require the same cellular involvement as does in case of catgut. Hydrolysis is increased with rise in temperature or $\mathrm{pH}$ changes. ${ }^{8,9}$

\section{Nonabsorbable Sutures}

The term nonabsorbable suture implies that the suture is either left in the body, where it becomes embedded in scar tissue, or it is removed when healing is complete. It is used in the tissue that heals more slowly than those requiring any type of absorbable sutures.

GE Lilly, DB Osbon, RA Hutchinson, RH H eflinch, did a study to determine whether polyglycolic acid sutures inhibit transmission of bacteria and the results were such that the biological findings showed that polyglycolic acid sutures do inhibit transmission of bacteria, even in our study the polyglycolic acid suture does inhibit transmission of bacteria. $^{2}$

Steven D Macht, Thomas J Krizek ${ }^{3}$ in their study revealed that nonabsorbable suture material requires removal, therefore, absorbable sutures are better. This study totally agrees with our study because absorbable sutures showed better quality results compared with black silk sutures.

K nut A Selwig, Guy R Biagiantti, Kunt N Leknes, Wikesjo ME in their study, examined tissue reactions to different types of suture materials. On the basis of type and intensity, the results of this study do coincide with our study due to a prolong tissue response, when placed in gingiva and oral mucosa than in other surgical compartments. ${ }^{10}$

Greenwald D, Shumway S, A lbear P, Gottlieb L conducted a study to compare standard absorbable sutures with synthetic absorbable suture and also to check tissue inflammatory reaction, knot security, suture tensile strength and suture absorption. This study does correl ate to our study; showed that black silks had milder response than polyglycolic acid suture. ${ }^{11}$

M uglali M, Y Imaz N, Inal S, Guvenc T, in their study of suture material, associated minimal inflammatory response to induce less response and less severe adhesions. The tissue reaction results of this study showed very less significance whereas in our study too the histological results were not very significant. ${ }^{13}$

Lei-W ick M D, in their study, monofilament absorbable sutures were used to check retention strength. This study proved that there was prolonged breaking strength retention. When correlated to our study, the retention strength of polyglycolic acid suture and black silk suture was good. ${ }^{12}$ 
Clinical and Histological Comparison of Polyglycolic Acid Suture with Black Silk Suture after Minor Oral Surgical Procedure

M irkovic S, Mirkovic TD, Racey GL, Wallace WR, Cavaluris CJ, M arguard JV concluded that polylactic and polyglycolic acid sutures has handling capacity similar to that of silk, but the handling capacity of polyglycolic acid suture was better than black silk in our study. ${ }^{14}$

$M$ asini BD, Stinner DJ, W aterman SM, W enke $J C$ in a study, comparing vicryl with various suture materials histopathologically evaluated that vicryl produced the mildest tissue reaction; whereas in our study black silk had milder response than polyglycolic. ${ }^{15}$

\section{CONCLUSION}

The study hereby concludes that polyglycolic acid suture material is far superior than black silk suture on various criteria's like retention strength, tissue reaction, knotting capacity and handling characteristics. Polyglycolic acid suture material may be more ideal in day-to-day dental practice.

\section{REFERENCES}

1. Wallace WR, Maxwell GR, Cavalaris CJ, Columbus, Ohio. Comparison of polyglycolic acid suture to black silk. Chromic and plain catgut in human oral tissues. J Oral Surg 1970 Oct; $28: 739-45$

2. Lilly GE, Osbon DB, Hutchinson RA, Heflinch RH. Clinical and bacteriologic aspect of polyglycolic acid sutures. J Oral Surg $1973 \mathrm{Feb} ; 31: 103-05$.

3. M acht SD, K rizek TJ. Sutures and suturing. Current Concepts 1978 Sep;36:710-12.

4. Racey GL, W allace W R, Cavaluris CJ, M arguard JV . Comparison of a polygtycolic-polylactic acid suture to black silk and plain catgut in human oral tissues. J Oral Surg 1978 Oct;36(10):766-70.

5. Artandi C. A revolution in sutures. Surg Gynecol and Obstet 1980 Feb;150:235-36.

6. Salthousc TN, Biologic response of sutures. Otolaryngol Head Neck Surg 1980 N ov-Dec;88(6):658-64.

7. V arma S, L umb WV , J ohnson LW, Ferguson HL. Further sutides with polyglycolic acid (Dcxon) and other sutures in infected experimental wounds. A m J V et Res 1981 A pril;42(4):571-74.

8. Ray JA, Doddi N, Regula D, W illiams JA, M elverger $A$, Somervillic. Polydioxanone, a novel monofllament synthetic absorbable suture. Surgery Gyn O bstet 1981 Oct;153:497-507.
9. Kaletsch $B$, Rehm KE, Stambolis $C$. Tissue reaction in microvessel anastomoses. Comparative study of reasorbable and nonresorbabie suture material. Handchirmikrochir Plastchir 1982; 14(2):99-102.

10. Lerwick $E$, Louis M issouri ST. Studies one the efficiacy and safety of polydioxanone monofilament absorbable suture. Surg Gynecol and Obset 1983 Jan;156:51-55.

11. Greenwald D, Shumway S, A lbear P, Gottlieb L. M echanical comparison of 10 suture materials before and after in vivo incubation. J Surg Res 1994 A pr;56(4):372-77.

12. $Y$ altirik $M$, et al. Comparison of four different suture materials in soft tissues of rats. O ral Dis $2003 \mathrm{Nov} ; 9(6): 284-86$.

13. M uglali M, Y Imaz N , Inal S, Guvenc T. Immunohistochemical comparison of indermil with traditional suture materials in dental surgery. J Craniofac Surg 2011 Sep;22(5):1875-79.

14. M irkovic S, M irkovic TD. Influence of different types of surgical suture materials on mechanical damage of oral mucosa. Med Pregl $2011 \mathrm{M}$ ar-A pr;64(3-4):157-60.

15. M asini BD, Stinner DJ, W aterman SM, W enke JC. B acterial adherence to suture materials. J Surg Educ 2011 M ar-A pr; 68(2):101-04.

\section{ABOUT THE AUTHORS}

\section{R Balamurugan}

Reader, Department of Oral and M axillofacial Surgery, V ananchal Dental College and Hospital, Ranchi, J harkhand, India

\section{Masroor Mohamed}

Professor, D epartment of Oral and M axillofacial Surgery, Rajasthan Dental College and Hospital, Jaipur, Rajasthan, India

\section{Vijayendra Pandey}

Reader, Department of Periodontology, V ananchal Dental College and Hospital, Ranchi, J harkhand, India

\section{Hari Krishna Rao Katikaneni}

Professor, Department of Oral and Maxillofacial Surgery, Bapuji Dental College and Hospital, D avangere, Karnataka, India

\section{KR Ashok Kumar (Corresponding Author)}

Professor, Department of Oral and M axillofacial Surgery, Sri Siddartha Dental College and Hospital, Agalakote, BH Road Tumkur-572107, K arnataka, India, Phone: 09845759894, e-mail: drashok.kumar26@gmail.com 